Bulletin d'études orientales

D'ETUDES

ORIENTALES

LXVII | 2020

Nouveaux itinéraires épigraphiques d'Orient et

d'Occident - Années 2018-2019

\title{
Comptes rendus mis en ligne en 2018-2019
}

\section{(2) OpenEdition \\ Journals}

Édition électronique

URL : http://journals.openedition.org/beo/6772

DOI : $10.4000 /$ beo. 6772

ISSN : 2077-4079

Éditeur

Presses de l'Institut français du Proche-Orient

Édition imprimée

Date de publication : 1 décembre 2020

Pagination : 9-9

ISBN : 978-2-35159-766-8

ISSN : 0253-1623

Référence électronique

"Comptes rendus mis en ligne en 2018-2019», Bulletin d'études orientales [En ligne], LXVII | 2020, mis en ligne le 20 janvier 2021, consulté le 22 janvier 2021. URL : http://journals.openedition.org/beo/6772 ; DOI : https://doi.org/10.4000/beo.6772 


\section{Comptes rendus mis en ligne en 2018-2019}

HILALI Asma, The Șan'a' Palimpsest. The transmission of the Qur'an in the first centuries AH., Oxford University Press, 2017, 271 pages.

ISBN: 9780198793793

(Hassan Bouali)

LARCHER Pierre, Syntaxe de l'arabe classique, Presses Universitaires de Provence (PUP), 2017, 340 pages. ISBN: 9791032001288

(Catherine Pinon)

GIROD Alain, Aziz Emad, Grammaire de l'arabe égyptien d'aujourd'hui, Ellipses, Paris, 2016, 199 pages.

ISBN: 9782340009875

(Catherine Pinon) 